\title{
PENERAPAN PENDEKATAN SAINTIFIK DALAM MATA PELAJARAN IPS KELAS VII DI SMP NEGERI 2 SERIRIT
}

\author{
Nur Qibtiyah ${ }^{1}$, Naswan Suharsono², lyus Akhmad Haris ${ }^{3}$ \\ Program Studi Pendidikan Ekonomi \\ Universitas Pendidikan Ganesha \\ Singaraja, Indonesia
}

\begin{abstract}
e-mail: nurqibtiyah82@gmail.com¹. naswansuharsono@gmail.com². iyusharis55@gmail.com ${ }^{3}$
\end{abstract}

\begin{abstract}
Abstrak
Penelitian ini bertujuan untuk mendeskripsikan perangkat pembelajaran yang dibuat guru sudah sesuai dengan Kurikulum 2013, penerapan pendekatan saintifik, dan keterlaksanaan penerapan pendekatan saintifik dalam mata pelajaran IPS kelas VII di SMP Negeri 2 Seririt. Data dikumpulkan dengan observasi, wawancara, dan dokumentasi. Selanjutnya dianalisis secara deskriptif. Hasil penelitian menunjukkan bahwa perangkat pembelajaran yang dibuat guru yaitu, pemetaan $S K L, K I$, dan KD, silabus, RPP, program tahunan, dan program semester. Sedangkan perangkat pembelajaran Kurikulum 2013 yang seharusnya dimiliki guru diwujudkan dalam buku kerja. Dalam penerapan pendekatan saintifik, kegiatan pembelajaran dalam mata pelajaran IPS di kelas VII B telah dilaksanakan sesuai dengan langkah-langkah pendekatan saintifik. Pada pelaksanaan pembelajaran IPS di kelas VII, guru dihadapkan berbagai hambatan yaitu ada beberapa siswa yang belum lancar membaca dan ada siswa yang terlambat masuk kelas karena sedang mendapat hukuman akibat dari melanggar peraturan sekolah. Adapun solusi yang dilakukan guru adalah bagi siswa yang tidak bisa membaca diberikan pembinaan khusus dan bagi siswa yang melanggar diarahkan untuk meningkatkan kedisiplinan.
\end{abstract}

Kata kunci: perangkat pembelajaran, pendekatan saintifik, hambatan, solusi.

\begin{abstract}
The study aimed at describing the learning set designed by the teacher in accordance with 2013 curriculum, the application of scientific approach, and the impelementation of scientific approach application at social science in the seventh gerade at SMP Negeri 2 Seririt. The data was collected by the using observation, interview, and documentation. Than it was analyzed descriptively. The result of the study show that the learning tools made by the teacher are, mapping graduate competency standards, core competencies, and basic competencies, syllabus, lesson plan, annual program, and semester program. While the 2013 curriculum learning tools that teachers should have are realized in a workbook. In applying the scientific approach, learning activities in social studies subjects in class VII B have been carried out accordance to the steps of the scientific approach. In the implementation of social studies learning in class VII, teachers are faced with various obstacles there are some students who have not read fluently and there are students who are late in class because they are being punished due to violating school rules. As for the solution made by the teacher is for students who cannot read given special guidance and for students who violate directed to improve discipline.
\end{abstract}

Keywords : learning tools, scientific approach, obstacles, solutions 


\section{PENDAHULUAN}

Berdasarkan Undang-Undang No. 20 Tahun 2003 tentang sistem pendidikan nasional bahwa pendidikan adalah suatu usaha sadar dan terencana untuk mewujudkan suasana belajar dan proses pembelajaran agar peserta didik secara aktif mengembangkan potensi dirinya untuk memiliki kekuatan spiritual keagamaan, pengendalian diri, dan masyarakat. Pendidikan memberikan kemungkinan pada siswa untuk memperoleh kesempatan, harapan, dan pengetahuan agar dapat hidup secara lebih baik. Besarnya kesempatan dan harapan bergantung pada kualitas pendidikan yang di tempuh. Pendidikan juga dapat menjadi kekuatan untuk melakukan perubahan agar sebuah kondisi menjadi lebih baik. Pendidikan yang berkualitas tentunya melibatkan siswa untuk aktif belajar dan mengarahkan terbentuknya nilai-nilai yang dibutuhkan oleh siswa dalam menempuh kehidupan.

Kondisi bangsa di masa datang, sangat dipengaruhi oleh pola pikir masyarakat yang terbentuk melalui suatu proses pendidikan. Proses pendidikan yang terarah akan membawa bangsa ini menuju peradaban yang lebih baik. Sebaliknya proses pendidikan yang tidak terarah, hanya akan menyita waktu, tenaga, serta dana tanpa ada hasil. Maka dibutuhkan usaha untuk meningkatkan mutu pendidikan di Negara Republik Indonesia ini. Sukses tidaknya pendidikan dipengaruhi oleh beberapa faktor, salah satu faktor yang penting adalah kurikulum.

Kurikulum merupakan salah satu alat untuk mencapai tujuan pendidikan, dan sekaligus digunakan sebagai pedoman dalam pelaksanaan proses belajar mengajar pada berbagai jenis dan tingkat sekolah. Kurikulum menjadi dasar dan cermin falsafah pandangan hidup suatu bangsa, akan diarahkan kemana dan bagaimana bentuk kehidupan bangsa ini di masa depan, semua itu ditentukan dan digambarkan dalam suatu kurikulum pendidikan. Dalam UU Sisdiknas No. 20 tahun 2003 bahwa kurikulum adalah seperangkat rencana dan pengaturan mengenai tujuan, isi dan bahan pelajaran serta cara yang digunakan sebagai pedoman penyelenggaraan kegiatan pembelajaran untuk mencapai tujuan tertentu.

Mengingat pentingnya kurikulum dalam pendidikan dan kehidupan manusia, maka penyusunan kurikulum tidak dapat dilakukan secara sembarangan. Penyusunan kurikulum membutuhkan landasan yang kuat, yang didasarkan pada hasil-hasil pemikiran dan penelitian yang mendalam. Penyusunan kurikulum yang tidak didasarkan pada landasan yang kuat dapat berakibat fatal terhadap kegagalan pendidikan itu sendiri. Kurikulum disusun untuk mewujudkan tujuan pendidikan nasional dengan memperhatikan tahap perkembangan peserta didik dan kesesuaiannya dengan lingkungan, kebutuhan pembangunan nasional, perkembangan ilmu pengetahuan dan teknologi serta kesenian, sesuai dengan jenis dan jenjang masing-masing satuan pendidikan. Kurikulum di Indonesia sejak jaman kemerdekaan sampai sekarang mengalami banyak perubahan. Kurikulum yang diberlakukan di Indonesia adalah Kurikulum 2013.

Kurikulum 2013 merupakan pengembangan dari Kurikulum Tingkat Satuan Pendidikan (KTSP) yang diberlakukan mulai tahun ajaran 2013/2014. Kurikulum 2013 telah memenuhi dua dimensi kurikulum yaitu rencana dan pengaturan mengenai tujuan, isi, dan bahan pelajaran, serta cara yang digunakan untuk kegiatan pembelajaran. Kurikulum 2013 bertujuan untuk mempersiapkan manusia Indonesia agar memiliki kemampuan hidup sebagai pribadi dan warga negara yang beriman, produktif, kreatif, inovatif, dan afektif serta mampu berkontribusi pada kehidupan bermasyarakat, berbangsa, bernegara, dan peradaban dunia.

Kurikulum 2013 menekankan pada pembelajaran menggunakan pendekatan saintifik (scientific approach) karena pendekatan ini dinilai sesuai untuk pengembangan sikap, pengetahuan, dan keterampilan. Pendekatan saintifik dimaksudkan untuk memberikan pemahaman kepada peserta didik dalam mengenal, memahami berbagai materi 
menggunakan pendekatan ilmiah, bahwa informasi bisa berasal dari mana saja, kapan saja, tidak bergantung pada informasi searah dari guru.

Adapun pengertian mengenai pendekatan saintifik menurut Musfiqon dan Nurdyansyah (2015) adalah pendekatan yang menggunakan langkahlangkan serta kaidah ilmiah dalam proses pembelajaran. Langkah ilmiah yang diterapkan meliputi menemukan masalah, merumuskan masalah, mengajukan hipotesis, mengumpulkan data, menganalisis data, dan menarik kesimpulan. Sejalan dengan pendapat tersebut, Hosnan (2014) berpendapat bahwa pendekatan saintifik adalah proses pembelajaran yang dirancang sedemikian rupa agar peserta didik secara aktif mengonstruk konsep, hukum atau prinsip ketika pembelajaran berlangsung. Tahapan-tahapan yang dilakukan yaitu mengamati (untuk mengidentifikasi atau menemukan masalah), merumuskan masalah, mengajukan atau merumuskan hipotesis, mengumpulkan data dengan berbagai teknik, menganalisis data dan menarik kesimpulan dan mengomunikasikan konsep, hukum, atau prinsip yang telah ditemukan. Selain itu, pembelajaran dengan menggunakan pendekatan saintifik pembelajaran menjadi lebih aktif, pembelajaran berpusat pada siswa, serta guru tidak berperan aktif dalam pembelajaran. Kemudian hasil belajar yang diharapkan yaitu mampu melahirkan peserta didik yang produktif, kreatif, inovatif, afektif melalui penguatan sikap, keterampilan, dan pengetahuan yang terintegrasi.

Merujuk pada pedoman Kurikulum 2013 Kompetensi Dasar Sekolah Menengah Pertama/Madrasah Tsanawiyah yang dikeluarkan dalam Kementerian Pendidikan dan Kebudayaan Tahun 2013 bahwa dalam pelaksanaan pendekatan saintifik memiliki 5 tahapan kegiatan inti yaitu sebagai berikut. Pertama kegiatan mengamati ialah kegiatan mengidentifikasikan ciri-ciri objek tertentu dengan alat inderanya secara teliti, menggunakan fakta yang relevan dan memulai dari hasil pengamatan, menggunakan alat atau bahan sebagai alat untuk mengamati objek dalam rangka pengumpulan data atau informasi dan dilakukan dengan cara lima indera. Dalam hal ini guru menyajikan perangkat pembelajaran berupa media pembelajaran, dalam kegiatan mengamati, guru menyajikan video, gambar, miniature, tayangan atau obyek asli. Siswa bisa diajak untuk bereksplorasi mengenai obyek yang akan dipelajari. Dalam kegiatan mengamati, mengutamakan kebermaknaan proses pembelajaran (meaningfull learning). Metode ini memiliki keunggulan tertentu, seperti menyajikan media objek secara nyata, peserta didik senang dan tertantang, dan mudah pelaksanaannya. Metode mengamati sangat bermanfaat bagi pemenuhan rasa ingin tahu peserta didik sehingga proses pembelajaran memiliki kebermaknaan yang tinggi. Adapun kompetensi yang diharapkan adalah melatih kesungguhan, ketelitian, dan mencari informasi.

Kedua kegiatan menanya adalah mengajukan pertanyaan tentang informasi yang tidak dipahami dari apa yang diamati atau pertanyaan untuk mendapatkan informasi tambahan tentang apa yang diamati (dimulai dari pertanyaan faktual sampai ke pertanyaan yang bersifat hipotik). Kompetensi yang dikembangkan adalah kreativitas, rasa ingin tahu, kemampuan merumuskan pertanyaan untuk membentuk pikiran kritis yang perlu untuk hidup cerdas dan belajar sepanjang hayat. Pada langkah ini suasana pembelajaran yang berhasil adalah terjadinya komunikasi aktif diskusi materi pelajaran. Guru perlu membimbing peserta didik untuk dapat mengajukan pertanyaan-pertanyaan tentang hasil pengamatan objek yang konkret sampai pada yang abstrak berkenaan dengan fakta, konsep, prosedur, ataupun hal lain yang lebih abstrak. Pertanyaan yang bersifat faktual sampai pada pertanyaan yang bersifat hipotik. Dari situasi dimana peserta didik dilatih menggunakan pertanyaan dari guru, masih memerlukan bantuan guru untuk mengajukan pertanyaan sampai ke tingkat dimana peserta didik mampu mengajukan pertanyaan secara mandiri. Melalui kegiatan bertanya dikembangkan rasa 
ingin tahu peserta didik. Semakin terlatih dalam bertanya, maka rasa ingin tahu semakin dapat dikembangkan. Pertanyaan tersebut menjadi dasar untuk mencari informasi yang lebih lanjut dan beragam dari sumber yang ditentukan guru sampai yang ditentukan peserta didik, dari sumber yang tunggal sampai sumber yang beragam.

Ketiga kegiatan mencoba adalah melakukan eksperimen, membaca sumber lain selain buku test, mengamati objek/kejadian/aktivitas, wawancara dengan narasumber. Kompetensi yang dikembangkan adalah mengembangkan sikap teliti, jujur, sopan, menghargai pendapat orang lain, kemampuan berkomunikasi, menerapkan kemampuan mengumpulkan informasi melalui berbagai cara yang dipelajari, mengembangkan kebiasaan belajar dan belajar sepanjang hayat. Pada langkah pembelajaran ini, setiap siswa dituntut untuk mencoba mempraktikkan apa yang dipelajari. Eksperimen atau mencoba dapat didefinisikan sebagai kegiatan terinci yang direncanakan untuk menghasilkan data untuk menjawab suatu masalah atau menguji sesutau hipotesis. Eksperimen atau mencoba dapat didefinisikan sebagai kegiatan terinci yang direncanakan untuk menghasilkan data untuk menjawab suatu masalah atau menguji sesuatu hipotesis. Suatu eksperimen akan berhasil jika variabel yang dimanipulasi dan jenis respons yang diharapkan dinyatakan secara jelas dalam suatu hipotesis, juga kondisi-kondisi yang akan dikontrol sudah tepat. Untuk keberhasilan ini, maka setiap eksperimen harus dirancang dulu kemudian diuji coba.

Kegiatan keempat yaitu menalar. Istilah "menalar" (associating) dalam kerangka proses pembelajaran dengan pendekatan ilmiah yang dianut dalam Kurikulum 2013 untuk menggambarkan bahwa guru dan peserta didik merupakan pelaku aktif. Titik tekannya tentu dalam banyak hal dan situasi peserta didik harus lebih aktif dari pada guru. Penalaran adalah proses berfikir yang logis dan sistematis atas fakta-fakta empiris yang dapat di observasi untuk memperoleh simpulan berupa pengetahuan. Kegiatan belajarnya adalah pertama, mengolah informasi yang sudah dikumpulkan baik terbatas dari hasil kegiatan mengumpulkan atau eksperimen maupun hasil dari kegiatan mengamati dan kegiatan mengumpulkan informasi. Kedua, pengolahan informasi yang dikumpulkan dari yang bersifat menambah keluasaan dan kedalaman sampai kepada pengolahan informasi yang bersifat mencari solusi dari berbagai sumber yang memiliki pendapat yang berbeda sampai kepada yang bertentangan. Pengolahan informasi yang dikumpulkan dari yang bersifat menambah keluasan dan kedalaman sampai kepada pengolahan informasi yang bersifat mencari solusi dari berbagai sumber yang memiliki pendapat yang berbeda sampai kepada yang bertentangan. Kegiatan ini dilakukan untuk menemukan keterkaitan satu informasi dengan informasi lainnya, menumakan pola dari keterkaitan informasi tersebut. Kompetensi yang dikembangkan adalah mengembangkan sikap jujur, teliti, disiplin, taat aturan, kerja keras, kemampuan menerapkan prosedur dan kemampuan berfikir induktif serta deduktif dalam menyimpulkan. Pada kegiatan ini siswa akan menalar yaitu menghubungkan apa yang sedang dipelajari dengan apa yang ada dalam kehidupan sehari-hari.

Kegiatan yang terakhir yaitu mengomunikasikan. Dalam kegiatan ini diharapkan guru memberi kesempatan kepada peserta didik untuk mengomunikasikan apa yang telah mereka pelajari. Pada tahapan ini, diharapkan peserta didik dapat mengomunikasikan hasil pekerjaan yang telah disusun baik secara bersama-sama dalam kelompok dan atau secara individu dari hasil kesimpulan yang telah dibuat bersama. Kegiatan mengomunikasikan ini dapat diberikan klarifikasi oleh guru agar peserta didik akan mengetahui secara benar apakah jawaban yang telah dikerjakan sudah benar atau ada yang harus diperbaiki. Kegiatan ini dapat dilakukan melalui menuliskan atau menceritakan apa yang ditemukan dalam kegiatan mencari informasi, mengasosiasikan dan menemukan pola. Hasil tersebut disampaikan di kelas dan 
dinilai oleh guru sebagai hasil belajar peserta didik atau kelompok peserta didik tersebut. Adapun kompetensi yang diaharapkan dalam kegiatan ini adalah mengembangkan sikap jujur, teliti, toleransi, kemampuan berfikir sistematis, mengungkapkan pendapat dengan singkat dan jelas, dan mengembangkan kemampuan berbahasa yang baik dan benar. Dalam kegiatan mengomunikasikan, peserta didik diharapkan sudah dapat mempersentasikan hasil temuannya untuk kemudian ditampilkan di depan khalayak ramai sehingga rasa berani dan percaya dirinya dapat lebih terasah. Peserta didik yang lain pun dapat memberikan komentar, saran, atau perbaikan mengenai apa yang dipresentasikan oleh rekannya.

Kelima langkah ini diharapkan siswa menjadi lebih aktif, berfikir kritis, mandiri, dan mau bekerjasama dengan teman sehingga mempermudah pemahaman siswa terhadap materi pelajaran.

Di SMP Negeri 2 Seririt baru diterapkan Kurikulum 2013 pada tahun pelajaran 2017/2018 tetapi hanya diberlakukan untuk kelas VII saja, dan Kurikulum 2006 (KTSP) diberlakukan untuk kelas VIII dan kelas IX. Dalam penerapan pendekatan saintifik guru masih menemukan berbagai hambatan terkait pembelajaran IPS. Selain masih terasa baru, pendekatan saintifik juga masih terasa asing bagi guru. Oleh karena itu, peneliti ingin mengkaji tentang penerapan pendekatan saintifik yang dilakukan guru di kelas, kemudian hambatan yang dialami guru dalam menerapkan pendekatan saintifik dalam pembelajaran IPS serta solusi yang dapat ditempuh untuk menyelesaikan permasalahan tersebut.

Oleh karena itu, maka peneliti perlu melakukan penelitian tentang "Penerapan Pendekatan Saintifik dalam Mata Pelajaran IPS Kelas VII di SMP Negeri 2 Seririt".

\section{METODE}

Penelitian ini merupakan penelitian deskriptif. Penelitian deskriptif adalah penelitian yang dilakukan untuk mengetahui nilai variabel mandiri, baik satu variabel atau lebih (independent) tanpa membuat perbandingan (Siregar, 2010). Penelitian ini memberikan gambaran (deskriftif) secara menyeluruh tentang perangkat pembelajaran yang dibuat guru, penerapan pendekatan saintifik, dan keterlaksanaan penerapan pendekatan saintifik dalam pembelajaran IPS.

Subjek penelitian ini adalah guru IPS kelas VII SMP Negeri 2 Seririt yang berjumlah satu orang. Adapun objek dari penelitian ini adalah pelaksanaan Kurikulum 2013.

Penelitian ini menggunakan dua jenis data yaitu data primer dan data sekunder. Data primer merupakan data yang diperoleh dari sumber pertama. Data primer dalam penelitian ini berupa hasil wawancara dan aktivitas guru dalam penerapan pendekatan saintifik mata pelajaran IPS, sedangkan data sekunder merupakan data yang diperoleh dari sumber kedua. Data sekunder dalam penelitian ini data berupa dokumendokumen perangkat pembelajaran dan nilai hasil belajar siswa kelas VII B.

Metode pengumpulan data yang digunakan dalam penelitian ini yaitu sebagai berikut. Observasi digunakan untuk mengumpulkan data yang berkenaan dengan aktivitas guru dalam menerapkan pendekatan saintifik pada mata pelajaran IPS selama proses pembelajaran di dalam kelas. Wawancara dalam penelitian ini digunakan untuk mengumpulkan data terkait permasalahan yang dialami oleh guru ketika mengimplementasikan pendekatan saintifik pada pembelajaran IPS. Dokumentasi ini digunakan untuk mengumpulkan data berupa perangkat pembelajarandan foto proses belajar mengajar di dalam kelas VII B.

\section{HASIL DAN PEMBAHASAN \\ Hasil Penelitian}

Berdasarkan data hasil penelitian mengenai perangkat pembelajaran yang dibuat guru yaitu, pemetaan SKL, KI, dan $\mathrm{KD}$, silabus, RPP, program tahunan, dan program semester. Sedangkan perangkat pembelajaran Kurikulum 2013 yang 
seharusnya dimilki guru diwujudkan dalam buku kerja. Buku kerja guru terdiri dari empat buku yaitu buku kerja guru satu berisi berisi tentang $S K L, K I$, dan $K D$, silabus, Rencana Pelaksanaan Pembelajaran (RPP), dan KKM. Buku kerja dua kode etik guru, ikrar guru, tata tertib guru, pembiasaan guru, kalender pendidikan, alokasi waktu, program tahunan, dan program semester. Buku kerja tiga berisi tentang daftar hadir, jadwal mengajar, penilaian, daya serap siswa, jurnal pembelajaran, daftar buku pegangan guru atau siswa, analisis butir soal UAS, analisis ulangan dan pengayaan, soal dan kisi-kisi soal. Yang terakhir buku kerja empat berisi tentang program evaluasi diri dan program tindak lanjut.

Dalam pembelajaran IPS kelas VII $B$ di SMP Negeri 2 Seririt dengan pendekatan saintifik memiliki 5 (lima) langkah pokok yaitu mengamati, menanya, mencoba, menalar, dan mengomunikasikan. Pada kegiatan mengamati guru meminta siswa untuk membaca materi tentang kehidupan masyarakat Indonesia pada masa HinduBudha. Dalam kegiatan mengamati guru tidak hanya diam tetapi guru juga menjelaskan materi pembelajaran secara runtut sehingga siswa dapat menyimak dengan baik penjelasan guru mengenai materi kehidupan masyarakat Indonesia pada masa Hindu-Budha. Dalam proses pembelajaran guru tidak menggunakan media pembelajaran karena gambar sudah ada di buku siswa sehingga siswa lebih mudah dalam mengamati gambar.

Pada kegiatan menanya terjadi interaksi tanya jawab antara guru dan siswa. Pada saat menyampaikan materi guru tidak hanya menjelaskannya saja, tetapi guru juga mengajak siswa untuk berinteraksi tanya jawab terhadap materi yang telah disampaikan. Selanjutnya guru memberi jawaban atas pertanyaan yang diajukan siswa. Setelah melakukan sesi tanya jawab, guru meminta siswa untuk membentuk kelompok yang masingmasing terdiri dari 8 (delapan) orang. Yang kemudian siswa diminta untuk membuat peta konsep (mind map) sesuai dengan kreasi masing-masing.
Yang ketiga kegiatan mencoba. Pada kegiatan ini guru meminta siswa jawaban atas permasalahan yang diperolehnya. Guru memberikan kesempatan kepada siswa untuk mencari refrensi lain terkait jawaban yang akan dihasilkan. Dalam hal ini guru memberikan batasan waktu selama 15 menit.

Kegiatan yang selanjutnya yaitu menalar. Pada kegiatan ini guru memberikan kesempatan kepada siswa untuk mengolah informasi yang telah diperolehnya. Kemudian guru meminta siswa untuk mendiskusikan jawaban yang diperolehnya. Selanjutnya tahap yang terakhir guru meminta siswa untuk menyimpulkan hasil pekerjaannya.

Kegiatan yang terakhir yaitu mengomunikasikan. Pada kegiatan ini guru meminta siswa untuk mempresentasikan hasil dari kegiatan yang mereka lakukan sebelumnya. Kemudian guru mengarahkan agar kelompok lain memberi tanggapan kepada teman yang persentasi di depan. Selanjutnya hasil kegiatan yang dilaporkan kepada kelompok yang persentasi didepan kemudian kelompok lain menanggapi jawaban, baik itu menyanggah maupun menambahkan. Kemudian guru langsung memberikan tanggapan tentang hasil kegiatan yang dilaporkan oleh siswa dengan menjelaskan kembali menggunakan bahasa yang dapat dimengerti oleh siswa. Tahap yang terakhir guru membantu siswa untu menyimpulkan hasil diskusi tujuannya agar semua siswa mendapatkan pemahaman yang sama.

Berdasarkan uraian di atas, dapat disimpulkan bahwa kegiatan pembelajaran dengan pendekatan saintifik dalam mata pelajaran IPS di kelas VII B telah dilaksanakan sesuai dengan langkahlangkah pendekatan saintifik, yaitu mengamati, menanya, mencoba, menalar, dan mengomunikasikan.

Pada pelaksanaan pembelajaran IPS di kelas VII guru dihadapkan berbagai hambatan yaitu ada beberapa siswa kelas VII yang belum lancar membaca. Yang kedua, ada siswa yang terlambat masuk kelas karena sedang mendapat hukuman akibat dari melanggar peraturan sekolah. 
Hal inilah yang menyebabkan pada saat pembelajaran dimulai tidak semua siswa dapat mengikutinya. Setiap permasalahan yang dihadapi tentu membutuhkan solusi yang tepat untuk mengatasinya. Adapun solusi-solusi yang dilakukan yaitu bagi siswa yang tidak bisa membaca diberikan pembinaan khusus seperti pengenalan huruf dan pelatihan membaca yang dipandu oleh guru mata pelajaran atau wali kelas dan bagi siswa yang melanggar diarahkan untuk meningkatkan kedisiplinan dengan memberikan teguran supaya siswa datang ke sekolah tepat waktu.

Kemudian peran kepala sekolah dan waka kurikulum dalam mengatasi permasalahan yang dialami guru yaitu dengan memanggil orang tua siswa atau ditangani oleh guru BK untuk mendapatkan pengarahan agar bisa menjadi siswa yang baik dan taat peraturan.

\section{Pembahasan}

Bagi seorang guru, melakasanakan tugas mengajar memerlukan desain yang terstruktur sesuai dengan kurikulum yang berlaku. Hal ini bertujuan agar proses pembelajaran bisa berlangsung dengan tertib sesuai dengan tujuan pembelajaran. Oleh karena itu, perlu dibuat perangkat administrasi yang disebut buku kerja sebagai panduan dalam melaksanakan tugasnya sebagai guru.

Buku kerja merupakan panduan yang dibuat oleh guru untuk mengontrol kinerja sebagai seorang guru. Buku kerja guru Kurikulum 2013 salah satu hasil dari Bimtek Kurikulum Nasional yang akan diberlakukan pada tahun ajaran baru. Kelengkapan yang seharusnya dimiliki guru diwujudkan dalam buku kerja guru. Buku kerja guru terdiri dari empat buku yaitu buku kerja satu berisi tentang SKL, $\mathrm{KI}$, dan KD, silabus, Rencana Pelaksanaan Pembelajaran (RPP), dan KKM. Buku kerja dua kode etik guru, ikrar guru, tata tertib guru, pembiasaan guru, kalender pendidikan, alokasi waktu, program tahunan, dan program semester. Buku kerja tiga berisi tentang daftar hadir, jadwal mengajar, penilaian, daya serap siswa, jurnal pembelajaran, daftar buku pegangan guru atau siswa, analisis butir soal UAS, analisis ulangan dan pengayaan, soal dan kisi-kisi soal. Yang terakhir buku kerja empat berisi tentang program evaluasi diri dan program tindak lanjut.

Seperti yang sudah dipaparkan sebelumnya pada bagian perangkat pembelajaran yang dibuat oleh guru yang meliputi pemetaan SKL, KI, dan KD, silabus, Rencana Pelaksanaan Pembelajaran (RPP), program tahunan, dan program semester dapat disimpulkan bahwa perangkat pembelajaran yang dibuat oleh guru tidak sesuai dengan perangkat pembelajaran Kurikulum 2013. Hal ini disebabkan karena guru belum memenuhi kriteria dari buku kerja guru Kurikulum 2013. Selain itu dalam hal ini juga belum adanya sosialisasi terkait perkembangan perangkat pembelajaran Kurikulum 2013 di sekolah SMP Negeri 2 Seririt.

$$
\text { Dalam pembelajaran dengan }
$$
pendekatan saintifik memiliki 5 (lima) langkah pokok yaitu mengamati, menanya, mencoba, menalar, dan mengomunikasikan. Kegiatan pertama dalam pendekatan saintifik adalah mengamati/observasi. Metode observasi adalah salah satu strategi pembelajaran yang menggunakan kontekstual dan media asli dalam rangka membelajarkan siswa yang mengutamakan kebermaknaan proses pembelajaran. Pengamatan dilakukan pada hari senin, 8 April 2019 jam keempat dan kelima (pukul 10.20-11.40) di kelas VII B. Dalam kegiatan ini guru meminta siswa untuk membaca materi tentang kehidupan masyarakat Indonesia pada masa HinduBudha. Dalam hal ini guru tidak hanya diam tetapi guru juga menjelaskan materi pembelajaran secara runtut sehingga siswa dapat menyimak dengan baik penjelasan guru mengenai materi kehidupan masyarakat Indonesia pada masa Hindu-Budha. Pada saat proses pembelajaran guru tidak menggunakan media pembelajaran karena gambar sudah ada di buku siswa sehingga siswa lebih mudah dalam mengamati gambar. Kegiatan ini diharapkan guru membuka secara luas dan bervariasi kesempatan 
peserta didik untuk melakukan pengamatan melalui kegiatan: melihat, menyimak, mendengar, dan membaca yang diformulasikan pada skenario proses pembelajaran.

Langkah kedua pada pendekatan saintifik adalah menanya/quetioning. Kegiatan menanya adalah mengajukan pertanyaan tentang informasi yang tidak dipahami dari apa yang diamati (dimulai dari pertanyaan faktual sampai ke pertanyaan yang bersifat hipotik) (Hosnan, 2014). Dalam kegiatan ini dilakukan tanya jawab antara guru dengan siswa terkait materi yang sudah dipaparkan. Pada saat menyampaikan materi guru tidak hanya menjelaskannya saja, tetapi guru juga mengajak siswa untuk berinteraksi tanya jawab terhadap materi yang telah disampaikan. Selanjutnya guru memberi jawaban atas pertanyaan yang diajukan siswa. Setelah melakukan sesi tanya jawab, guru meminta siswa untuk membentuk kelompok yang masingmasing terdiri dari 8 (delapan) orang. Yang kemudian siswa diminta untuk membuat peta konsep (mind map) sesuai dengan kreasi masing-masing. Dalam kegiatan menanya, guru membuka kesempatan secara luas kepada peserta didik untuk bertanya mengenai fakta, konsep, prinsip atau prosedur yang sudah dilihat, disimak, dibaca atau dilihat. Guru perlu membimbing peserta didik untuk dapat menanya atau mengajukan pertanyaan tentang hasil pengamatan objek yang konkrit sampai kepada yang abstrak berkenaan dengan fakta, konsep, prosedur, ataupun hal lain yang lebih abstrak.

Kegiatan mencoba (experimenting) merupakan kelanjutan dari kegiatan bertanya. Kegiatan mencoba (experimenting) adalah melakukan eksperimen, membaca sumber lain selain buku test, mengamati objek/kejadian/aktivitas, wawancara dengan narasumber. Kompetensi yang dikembangkan adalah mengembangkan sikap teliti, jujur, sopan, menghargai pendapat orang lain, kemampuan berkomunikasi, menerapkan kemampuan mengumpulkan informasi melalui berbagai cara yang dipelajari, mengembangkan kebiasaan belajar dan belajar sepanjang hayat. Pada langkah pembelajaran ini, setiap siswa dituntut untuk mencoba mempraktikkan apa yang dipelajari (Hosnan, 2014). Pada kegiatan ini guru meminta siswa jawaban atas permasalahan yang diperolehnya. Guru memberikan kesempatan kepada siswa untuk mencari refrensi lain terkait jawaban yang akan dihasilkan. Dalam hal ini guru memberikan batasan waktu selama 15 menit. Menurut Peraturan Menteri Pendidikan dan Kebudayaan Republik Indonesia Nomor 81a Tahun 2013 menyatakan bahwa kegiatan ini guru melatih siswa untuk mengembangkan sikap teliti, jujur, sopan, menghargai pendapat orang lain, kemampuan berkomunikasi, menerapkan kemampuan mengumpulkan informasi melalui berbagai cara yang dipelajari, mengembangkan kebiasaan belajar dan belajar sepanjang hayat.

Berdasarkan Peraturan Menteri Pendidikan dan Kebudayaan Republik Indonesia Nomor 81a Tahun 2013 bahwa menalar dalam kegiatan pembelajaran adalah memproses informasi yang sudah dikumpulkan, baik terbatas dari hasil kegiatan mengumpulkan atau eksperimen maupun hasil dari kegiatan mengamati dari kegiatan mengumpulkan informasi. Dalam langkah ini guru memberikan kesempatan kepada siswa untuk mengolah informasi yang telah diperolehnya. Kemudian guru meminta siswa untuk mendiskusikan jawaban yang diperolehnya. Selanjutnya tahap yang terakhir guru meminta siswa untuk menyimpulkan hasil pekerjaannya. Dalam hal ini peran guru hanya mengawasi cara kerja siswa. Guru melatih agar siswa mampu berpikir secara kritis dan mampu memecahkan masalah sendiri.

Kegiatan belajar yang dilakukan pada tahapan mengkomunikasikan adalah menyampaikan hasil pengamatan, kesimpulan berdasarkan hasil analisis secara lisan, tertulis, atau media lainnya. Kegiatan lainnya adalah menuliskan atau menceritakan apa yang ditemukan dalam kegiatan mencari informasi, mengasosiasikan dan menemukan pola. Hasil tersebut disampaikan di kelas dan 
dinilai oleh guru sebagai hasil belajar peserta didik atau kelompok peserta didik tersebut. Kegiatan mengomunikasikan dalam pembelajaran IPS yaitu guru meminta siswa untuk mempresentasikan hasil dari kegiatan yang mereka lakukan sebelumnya. Kemudian guru mengarahkan agar kelompok lain memberi tanggapan kepada teman yang persentasi di depan. Selanjutnya hasil kegiatan yang dilaporkan kepada kelompok yang persentasi didepan kemudian kelompok lain menanggapi jawaban, baik itu menyanggah maupun menambahkan. Kemudian guru langsung memberikan tanggapan tentang hasil kegiatan yang dilaporkan oleh siswa dengan menjelaskan kembali menggunakan bahasa yang dapat dimengerti oleh siswa. Tahap yang terakhir guru membantu siswa untu menyimpulkan hasil diskusi tujuannya agar semua siswa mendapatkan pemahaman yang sama. Kegiatan mengomunikasikan bertujuan agar guru dapat mengembangkan sikap jujur, teliti, toleransi, kemampuan berpikir sistematis, mengungkapkan pendapat dengan singkat dan jelas, dan dapat mengembangkan kemampuan berbahasa yang baik dan benar terhadap siswa.

Berdasarkan hasil penelitian bahwa dalam melaksanakan penerapan pendekatan saintifik pada pembelajaran IPS guru mengalami hambatan yaitu sebagai berikut.

Pertama, ada beberapa siswa kelas VII yang belum lancar membaca karena minat baca masih rendah sehingga tingkat keberhasilan siswa dalam membaca akan sulit tercapai. Minat baca harus ditumbuhkembangkan sejak dini. Jika kegiatan membaca tidak dilakukan secara teratur maka minat membaca yang dimiliki siswa akan berkurang dengan sendirinya.

Kedua, ada siswa yang terlambat masuk kelas karena sedang mendapat hukuman akibat dari melanggar peraturan sekolah. Hal inilah yang menyebabkan pada saat pembelajaran dimulai tidak semua siswa dapat mengikutinya.

Setiap permasalahan yang dihadapi tentu membutuhkan solusi yang tepat untuk mengatasinya. Adapun solusi-solusi yang dilakukan adalah sebagai berikut.
Pertama, bagi siswa yang tidak bisa membaca diberikan pembinaan khusus seperti pengenalan huruf dan pelatihan membaca yang dipandu oleh guru mata pelajaran atau wali kelas. Karena membaca merupakan kemampuan yang harus dimiliki oleh semua siswa karena melalui membaca siswa dapat belajar banyak tentang berbagai bidang studi.

Kedua, bagi siswa yang melanggar diarahkan untuk meningkatkan kedisiplinan dengan memberikan teguran supaya siswa datang ke sekolah tepat waktu. Dalam hal ini peran kepala sekolah dan waka kurikulum dalam mengatasi permasalahan ini yaitu dengan memanggil orang tua siswa atau ditangani oleh guru BK untuk mendapatkan pengarahan agar bisa menjadi siswa yang baik dan taat peraturan. Selain itu, tindakan yang bisa dilakukan untuk cara mengatasi masalah disiplin di sekolah adalah dengan memberikan penyuluhan, pengertian dan pembinaan kepada siswa dan siswi di sekolah. Hal ini bertujuan untuk menumbuhkan kesadaran diri siswa untuk mau mematuhi peraturan sekolah dan mendisiplinkan diri. Siswa harus tahu manfaat dari peraturan yang dibuat dan harus sadar kenapa kedisiplinan diri itu sangat penting.

\section{SIMPULAN DAN SARAN \\ Simpulan}

Berdasarkan hasil penelitian dan pembahasan, dapat disimpulkan yaitu sebagai berikut. Pertama, perangkat pembelajaran yang dibuat oleh guru tidak sesuai dengan perangkat pembelajaran Kurikulum 2013. Hal ini disebabkan karena guru belum memenuhi kriteria dari buku kerja guru Kurikulum 2013. Selain itu dalam hal ini juga belum adanya sosialisasi terkait perkembangan perangkat pembelajaran Kurikulum 2013 di sekolah SMP Negeri 2 Seririt. Kedua, Penerapan pendekatan saintifik dalam mata pelajaran IPS di kelas VII B telah dilaksanakan sesuai dengan langkahlangkah pendekatan saintifik, yaitu mengamati, menanya, mencoba, menalar, dan mengomunikasikan. Ketiga, Ketelaksanaan penerapan pendekatan saintifik dalam pembelajaran IPS di kelas 
VII guru dihadapkan berbagai hambatan yaitu ada beberapa siswa yang belum lancar membaca dan ada siswa yang terlambat masuk kelas karena sedang mendapat hukuman akibat dari melanggar peraturan sekolah. Adapun solusi yang dilakukan oleh guru yaitu bagi siswa yang tidak bisa membaca diberikan pembinaan khusus seperti pengenalan huruf dan pelatihan membaca dan bagi siswa yang melanggar diarahkan untuk meningkatkan kedisiplinan agar siswa datang ke sekolah tepat waktu.

\section{Saran}

Berdasarkan temuan-temuan dalam penelitian ini, dapat disampaikan saransaran sebagai berikut. Kepada sekolah, diharapkan agar memberikan sosialisasi atau pelatihan-pelatihan kepada guru terkait perkembangan perangkat pembelajaran Kurikulum 2013, agar dapat memperbaiki perangkat pembelajaran yang sebelumnya dibuat oleh guru. Kepada guru IPS, diharapkan agar melakukan diskusi dan bertukar informasi dengan sesama guru IPS dalam Musyawarah Guru Mata Pelajaran (MGMP) diperlukan untuk mengatasi permasalahan yang dialami dalam penerapan pendekatan saintifik dengan baik dan menambah pemahaman tentang perangkat pembelajaran sehingga guru bisa mengembangkan perangkat pembelajaran siswa sesuai kebutuhan siswa di kelas yang tertuang dalam kegiatan persiapan dan pelaksanaan perangkat pembelajaran yang menunjang kelancaran proses belajar mengajar di kelas. Kepada peneliti selanjutnya, harus menunjukkan detail kesalahan pada perangkat pembelajaran terdahulu yang sudah dihasilkan, sehingga guru lebih paham dengan analisis kesalahan perangkat pembelajaran yang sudah ada.

\section{DAFTAR PUSTAKA}

Hosnan, M. 2014. Pendekatan Saintifik Dan Kontekstual Dalam Pembelajaran Abad 21 (Kunci Sukses Implementasi Kurikulum 2013). Bogor: Ghalia Indonesia.

Musfiqon dan Nurdyansyah. 2015.
Pendekatan Pembelajaran Saintifik. Siduarjo: Nizamia Learning Center.

Siregar, Sofyan. 2010. Statistika Deskriptif Untuk Penelitian. Jakarta: PT Raja Grafindo Persada. 